\title{
Development of a Crawler Type Vehicle to Travel in Water Paddy Rice Field for Water-Dropwort Harvest
}

\author{
Hyeon-Jong Jun*, Tae-Gyoung Kang, Yong Choi, Il-Su Choi, Duck-Kyu Choi, Choung-Keun Lee
}

National Academy of Agricultural Science, Rural Development of Administration, Suwon Korea

Received: October 24 ${ }^{\text {th }}, 2013$; Revised: November 17 ${ }^{\text {th }}, 2013$; Accepted: November $25^{\text {th }}, 2013$

\section{Abstract}

Purpose: This study was conducted to develop a rubber-crawler type vehicle as a traveling device for harvesting water-dropwort cultivated in water contained paddy rice field in winter season. Methods: A commercial rubber-crawler type vehicle was used to investigate application of rubber crawler to the paddy rice field as preliminary test. As the result of the preliminary test, a both prototype traveling device with rubber crawlers for a water-dropwort harvest was designed with inclination of $45^{\circ}$ at the front-end and rear-end of crawler under the basic water depth of $0.6 \mathrm{~m}$ in the paddy rice field. The device was fabricated and attached to the experimental harvesting test devices on the front of the prototype vehicle. The size of the prototype crawler vehicle with a harvesting part is 2,800 x 1,460 x 1,040 (mm) (LxWxH) with weight of 9.21 $\mathrm{kN}$ (maximum). Sizes of the crawler of prototype vehicle are ground contact length of $900 \mathrm{~mm}$, width of $180 \mathrm{~mm}$, height of $1,070 \mathrm{~mm}$ and distance between center to center of crawlers of $720 \mathrm{~mm}$. The side-overturn angle of the prototype was $26.4^{\circ}$. Results: Driving performance of the prototype vehicle in water contained paddy field were good at both forward and reverse (backward) directions as weights were applied. The drawbar pull and the maximum sinking depth of the prototype vehicle were $3.5 \mathrm{kN}$ and $0.13 \mathrm{~m}$ respectively at water depth of $0.5 \mathrm{~m}$, when the weight and bearing capacity of the prototype rubber crawler in the paddy field were $8.51 \mathrm{kN}$ and $26.3 \mathrm{kN} / \mathrm{m}^{2}$, respectively. Conclusions: Results of the driving test performance of the prototype crawler in paddy rice field at the water depth of $0.5 \mathrm{~m}$ were satisfactory. The prototype had enough drawbar pull and driving ability in the deep water contained paddy field.

Keywords: Crawler vehicle, Drawbar pull, Driving ability, Paddy field, Sinking depth, Water-dropwort

\section{Introduction}

Water-dropwort is cultivated in paddy rice field filled with water at maximum depth of $0.6 \mathrm{~m}$ during winter season in Korea. Water-dropwort harvesting is done manually and requires a lot of hard work in root digging using shovels and picking of roots for cleaning. The working environment is also harsh because of the water contained paddy fields.

In a related study by Jun, et al. (2009) and Jun, et al. (2011) on the mechanical harvesting for waterdropwort, it was shown that the sinking of a driving

\footnotetext{
*Comesponding author: Hyeon-Jong Jun

Tel: +82-31-290-1873; Fax: +82-31-290-1873

E-mail: hjjun@korea.kr
}

device should be considered as an important factor in the water-dropwort field such as in a water contained paddy field. As a result, the study recommended that a crawler type vehicle is needed to perform a reliable driving and to exert constant drawbar pull in a water contained paddy field.

Michael (1996) reported that it was possible to apply great wheel masses onto the soil without the danger of compaction with modern wide tires under the presupposition that pressure is evenly distributed in the contact area.

In respect of soil pressure the caterpillar has only a little advantage. High pressure rates are beneath the carrier rolls. At low slippage conditions the caterpillar is superior to the tractor. Assuming the same traction 
force; the caterpillar runs with $10 \%$ less slippage and is $10 \%$ faster with the same engine power and with all other influences constant, the output per unit area could be $10 \%$ bigger.

Park et al. (2003) developed a computer simulation program (TPPMTV98) to investigate the mechanical interrelation between soil characteristics and main design factors of a tracked vehicle, and predict the traction performance of the tracked vehicles. The effectiveness of the developed model was verified by comparing the predicted drawbar pulls using TPPMTV98 with measured ones from traction tests with a tracked vehicle reconstructed for test in loam soil with moisture content of $18.92 \%$, d.b.. The drawbar pulls measured by the TPPMTV98 were well matched to the measured ones.

Nikolic (1993) reported he tested the maximum net traction coefficient for Caterpillar Challenger 65 tractor which has rubber tracks, an articulated four wheel drive tractor with dual wheels and a mechanical front wheel drive tractor under an unplowed and plowed wheat stubble field.

The maximum net traction coefficient was established at the traction efficiency of 0.6 on the unplowed wheat stubble field; for the Challenger 65 tractor 0.855 ; 4WD; 0.624 and MFWD; 0.534 and on the plowed wheat stubble field with the traction efficiency of 0.4 for Challenger 65 tractor 0.82 ; 4WD 0.57 and for tractor MFWD 0.48 .

Matsuo et al. (1993) reported the equations to calculate the velocities, accelerations and penetration angle of the locus of lug motion for the rubber crawler mechanism.

Inaba et al. (2000) reported the simulation method to evaluate the travel resistance occurred by the rolling resistance of the track roller. The rolling resistance for each track roller arrangement and effects of the lug phase in the right and left rubber crawler could be estimated quantitatively.

In this study, for good travel performance in watercontained paddy rice field to develop a traveling vehicle for water-dropwort harvest, a commercialized rubber crawler vehicle was preliminarily tested to investigate the travel performance and sinking of the crawler type vehicle and then a prototype crawler vehicle was designed applying results of bearing capacity and shape of crawlers from the preliminary test. This study was conducted to develop a prototype crawler vehicle traveling in watercontained paddy field for water-dropwort.

\section{Materials and Methods}

\section{Field test for the commercial rubber crawler-type vehicle (HC-300C)}

\section{Field condition}

The test field was the water-contained paddy field of newly harvested water dropwort. Texture of soil of the test field was SiL (silt loam) at water depth of 0.2 $\mathrm{m}$. Soft ground layer thickness of the test field was 0.3 $\mathrm{m}$ and it has a very hard layer under the soft layer.

\section{Test device: the crawler vehicle (HC-300C)}

The test device used in the test was the commercial rubber crawler vehicle (model: HC-300C, Hanseo Precision Industry Co. Ltd.).

The test rubber crawler vehicle is a walking carrier with a maximum load capacity of $2.94 \mathrm{kN}$. It has a chain that efficiently transmits the engine power to the crawler without power loss. Figure 1 shows the schematic diagram of the test rubber crawler vehicle.

The crawler vehicle has a weight of $2.55 \mathrm{kN}$ and an allowable load of $2.94 \mathrm{kN}$. The rubber crawler of the vehicle has an average height of $270 \mathrm{~mm}$, width of 180
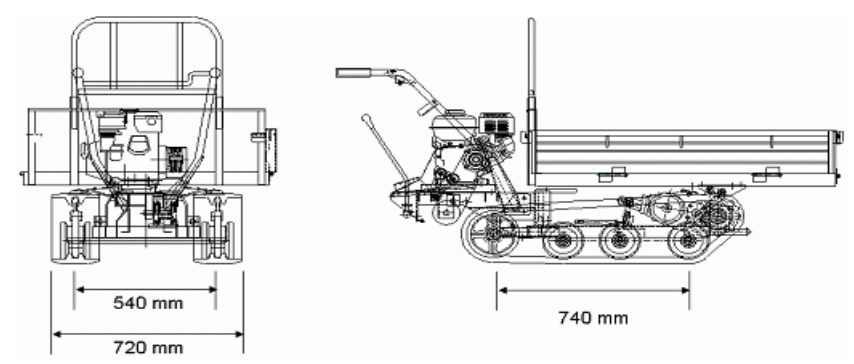

Figure 1. Schematic diagram of the test rubber crawler vehicle (HC-300C).

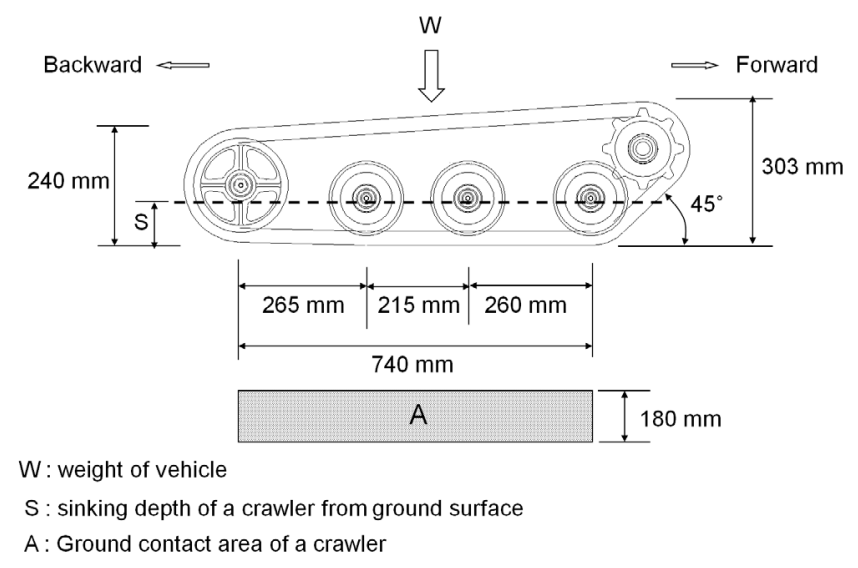

Figure 2. Structure of a crawler of the test vehicle (HC-300C). 
Table 1. Specification of the test rubber crawler vehicle

\begin{tabular}{|c|c|c|}
\hline Parameters & Unit & Value \\
\hline Weight of the test vehicle & $\mathrm{kN}$ & 2.55 \\
\hline Power of the test vehicle & $\mathrm{kW}$ & 5.1 \\
\hline Thickness of crawler & $\mathrm{mm}$ & 20 \\
\hline Ground contact length of crawler & $\mathrm{mm}$ & 740 \\
\hline Width of crawler & $\mathrm{mm}$ & 180 \\
\hline Lug height of crawler & $\mathrm{mm}$ & 15 \\
\hline Front height of crawler & $\mathrm{mm}$ & 303 \\
\hline Rear height of crawler & $\mathrm{mm}$ & 240 \\
\hline Front-end inclination of crawler & $\circ$ & 45 \\
\hline Rear-end radius of crawler & $\mathrm{mm}$ & 120 \\
\hline Lug pitch of crawler & $\mathrm{mm}$ & 65 \\
\hline Ground contact area of crawlers & $\mathrm{m}^{2}$ & 0.2664 \\
\hline
\end{tabular}

$\mathrm{mm}$ and ground contact length $740 \mathrm{~mm}$. The lug of the crawler has a height of $10 \mathrm{~mm}$ and pitch $65 \mathrm{~mm}$. The test crawler vehicle has an inclination of $45^{\circ}$ at front part and radius of $120 \mathrm{~mm}$ in semi circle at rear part. In addition, the fixed-type track rollers were placed in the rear sprocket with spaces of $265 \mathrm{~mm}, 215 \mathrm{~mm}$ and $260 \mathrm{~mm}$.

The structure of a crawler of the test vehicle (HC-300C) is shown in Figure 2 and the detailed specification of the test rubber crawler vehicle is presented in Table 1.

\section{Driving and drawbar pull test of the test rubber crawler vehicle}

Driving test for the test crawler vehicle was performed to determine the driving conditions for the test crawler vehicle with maximum weight of $5.49 \mathrm{kN}$ in water contained paddy field when running forward and backward. The water depth conditions of the test field were 0.05 $\mathrm{m}$ and $0.2 \mathrm{~m}$. The sinking depth of the rubber crawler was measured loading from the weight of $0.98 \mathrm{kN}$ to to $2.94 \mathrm{kN}$ on the test vehicle. This is taken from the difference of height between the bottom of the crawler and the ground from the water surface. Table 2 is the bearing capacity of the test vehicle for sinking depth measurement.

The drawbar pull testing was done at the paddy field with water depth of $0.05 \mathrm{~m}$ according to contact area of the test crawler vehicle. Drawbar pull of the test rubber crawler vehicle was tested by a load cell (allowable load $4.9 \mathrm{kN}$, CAS Co., Ltd) at the vehicle weight of 5.49 $\mathrm{kN}$. Data were acquired from the load cell by using the equipment DEWE 2010 (DEWETRON GmbH). Figure 3

\section{Table 2. Bearing capacity of the crawlers of the test vehicle}

\begin{tabular}{|cc|}
$\begin{array}{c}\text { The weight of test vehicle } \\
(\mathrm{kN})\end{array}$ & $\begin{array}{r}\text { Bearing capacity of the crawlers } \\
\left(\mathrm{kN} / \mathrm{m}^{2}\right)\end{array}$ \\
\hline 2.55 (test vehicle) & 9.57 \\
3.53 & 13.25 \\
4.51 & 16.93 \\
5.49 & 20.61 \\
\hline
\end{tabular}

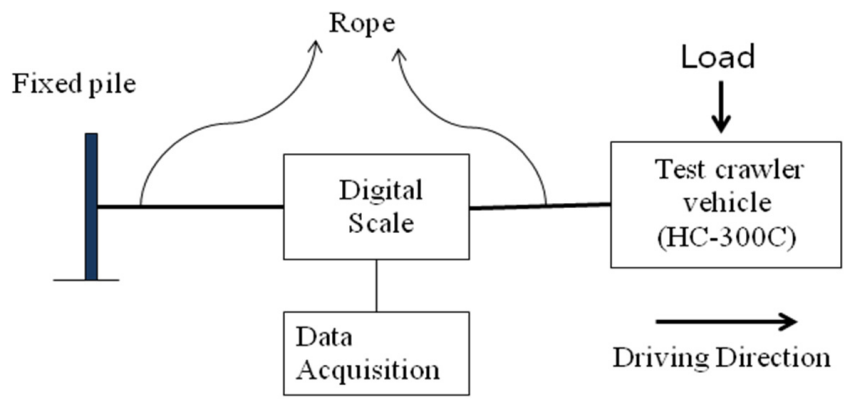

Figure 3. Schematic diagram of drawbar pull test.

is the schematic diagram of drawbar pull test of the test rubber crawler vehicle (HC-300C).

\section{Field testing of prototype rubber crawler-type vehicle}

\section{Design of the prototype vehicle}

The prototype rubber crawler-type vehicle was designed in triangle shape crawler to travel in water contained paddy field with water depth of $0.6 \mathrm{~m}$. Figure 4 shows the schematic diagram of prototype crawler vehicle. Distance between the crawlers of the prototype was determined into $720 \mathrm{~mm}$ with its traveling stability 

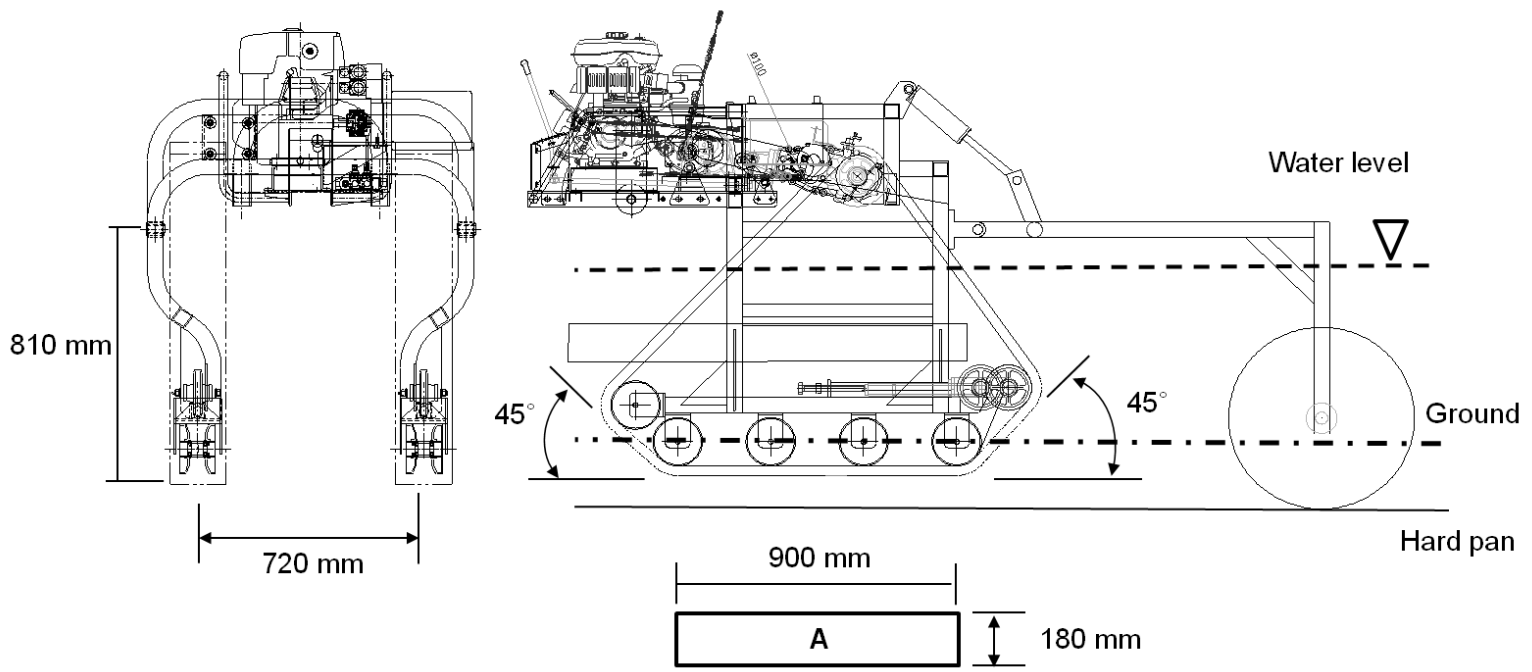

A : contact area of a crawler

Figure 4. Schematic diagram of prototype crawler vehicle.

Table 3. Specification of the prototype crawler vehicle

\begin{tabular}{lcc}
\multicolumn{1}{c}{ Parameters } & Unit & Value \\
Sizes of the prototype (LxWXH) & $\mathrm{mm}$ & $2800 \times 1040 \times 1460$ \\
Weight of the prototype(depending on weight) & $\mathrm{kN}$ & $5.59 \sim 9.21$ \\
Power of the prototype & $\mathrm{kW}$ & 5.1 \\
Thickness of rubber crawler & $\mathrm{mm}$ & 20 \\
Ground contact length of rubber crawler & $\mathrm{mm}$ & 900 \\
Width of rubber crawler & $\mathrm{mm}$ & 180 \\
Lug height of rubber crawler & $\mathrm{mm}$ & 15 \\
Front height of rubber crawler & $\mathrm{mm}$ & 303 \\
Rear height of rubber crawler & $\mathrm{mm}$ & 240 \\
\hline Front-end inclination of rubber crawler & $\circ$ & 45 \\
Rear-end inclination of rubber crawler & $\circ$ & 45 \\
Lug pitch of rubber crawler & $\mathrm{mm}$ & 65 \\
Ground contact area of rubber crawlers & $\mathrm{m}$ & 0.324 \\
\hline Track roller space & $\mathrm{mm}$ & 300 \\
\hline
\end{tabular}

and allowable working width of $1 \mathrm{~m}$ as basis for developing a water-dropwort harvester. Moreover the prototype crawler vehicle was designed to be able to attach the experimental harvesting test devices on the front of the prototype vehicle.

The ground contact length of the rubber crawler of the prototype vehicle was determined in consideration of drawbar pull, traveling stability and sinking depth from the test results for the test rubber crawler vehicle in the water contained paddy field.

The size of the prototype vehicle was $2,800 \times 1,040$ $\mathrm{x} 1,460(\mathrm{LxWxH}, \mathrm{mm})$ and the balance of the prototype vehicle was controlled by supplement of weights when a harvesting device is placed on the front of the prototype. The rubber crawler of the prototype vehicle has a ground contact length of $900 \mathrm{~mm}$, a width of $180 \mathrm{~mm}$, crawler height of $1,070 \mathrm{~mm}$ and an inner distance of $540 \mathrm{~mm}$, center distance of $720 \mathrm{~mm}$ and outer distance of $900 \mathrm{~mm}$ between the crawlers.

The shape of the rubber crawler was designed easy to travel in paddy field with inclination of $45^{\circ}$ both at front-end and rear-end of crawler to prevent the sinking of the crawler while driving back and forth in watercontained paddy field. The power and speeds of the 
prototype vehicle were $5.1 \mathrm{~kW}$ (gasoline engine) and $0.1 \sim 0.3 \mathrm{~m} / \mathrm{s}$. The detailed specification of the prototype crawler vehicle is shown in Table 3.

\section{Field testing for the prototype vehicle}

Side-overturn testing of prototype vehicle

A side-overturn test of the prototype vehicle was performed to find out a side-overturn angle of the prototype vehicle due to the differential sinking while driving in paddy field. A side-overturn angle of prototype vehicle was measured with one side rubber crawler of prototype fixed on the test plate and the other side rubber crawler free when the prototype vehicle is deviated by inclining the test plate of the side-overturn measuring device. Figure 5 shows measurement of the side-overturn angle of the prototype crawler vehicle.

\section{Driving and drawbar pull test}

The driving test of prototype vehicle was carried with the load acting on the rubber crawler according to the weight of harvest device attached on the front of the prototype vehicle.

As shown at the Table 4, the driving test of prototype vehicle was tested at 3 levels according to the weights of prototype $(5.59,7.64,9.21 \mathrm{kN})$ while the sinking of

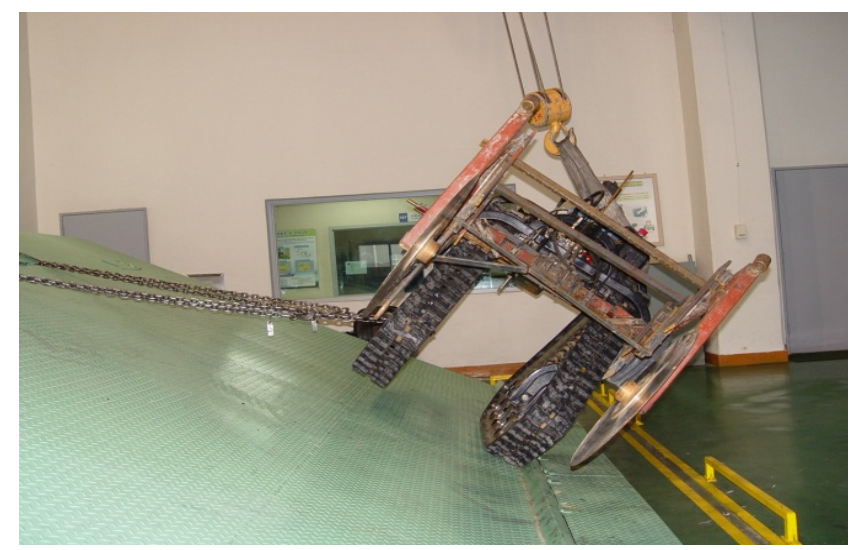

Figure 5. View of side-overturn test of the prototype vehicle.

\section{Table 4. Test conditions of driving test of the prototype vehicle}

\begin{tabular}{ccr} 
Parameter & Unit & \\
& & $5.59(17.25)$ \\
weight of prototype & $\mathrm{kN}$ & $7.64(23.58)$ \\
(bearing capacity of the & $\left(\mathrm{kN} / \mathrm{m}^{2}\right)$ & $9.21(28.42)$ \\
crawlers) & & $11.27(34.78)$ \\
Level of shift gear & & 3 Level( I , II, III) \\
Engine speed & $\mathrm{rpm}$ & 1,100 \\
\hline
\end{tabular}

the rubber crawlers was measured while performing each driving test. The driving speed of the prototype vehicle in the paddy field with water depth of $0.5 \mathrm{~m}$ was tested at 3 levels ( I, II, III) by running the prototype vehicle with three different speeds of gearshift at an engine speed of $1,100 \mathrm{rpm}$ and weight of $11.27 \mathrm{kN}$.

Drawbar pull of the prototype vehicle was tested at weight of $8.53 \mathrm{kN}$ of the prototype as shown at Figure 3.

\section{Results and Discussion}

\section{Field testing for the commercial rubber crawler vehicle (HC-300C)}

Sinking depth of the test rubber crawler vehicle

Figure 6 shows that sinking depth of the crawler of the vehicle was $0.05 \mathrm{~m}$ at the bearing capacity of $9.57 \mathrm{kN} / \mathrm{m}^{2}$ of the crawlers (at weight of $2.55 \mathrm{kN}$ of the test vehicle) and $0.1 \mathrm{~m}$ at the bearing capacity of $20.61 \mathrm{kN} / \mathrm{m}^{2}$ of the crawlers (at the weight of $5.49 \mathrm{kN}-2.55 \mathrm{kN}$ of the test crawler vehicle + load of $2.94 \mathrm{kN}$ ).

\section{Driving condition of the test rubber crawler vehicle}

Results of the driving test for the test rubber crawler vehicle showed that driving in the forward direction was possible under water depths of $0.05 \mathrm{~m}$ and $0.2 \mathrm{~m}$ at the bearing capacity of $9.57 \mathrm{kN}$ of the crawlers (vehicle weight of $2.55 \mathrm{kN}$ ) and at the bearing capacity of 20.61 $\mathrm{kN} / \mathrm{m}^{2}$ of the crawlers (vehicle weight of $5.49 \mathrm{kN}$ ) respectively.

However, at the bearing capacity of $20.61 \mathrm{kN} / \mathrm{m}^{2}$ of the crawlers (vehicle weight of $5.49 \mathrm{kN}$ ), driving in the reverse (backward) direction was difficult under water depths of $0.05 \mathrm{~m}$ and $0.2 \mathrm{~m}$ in the water paddy field. This

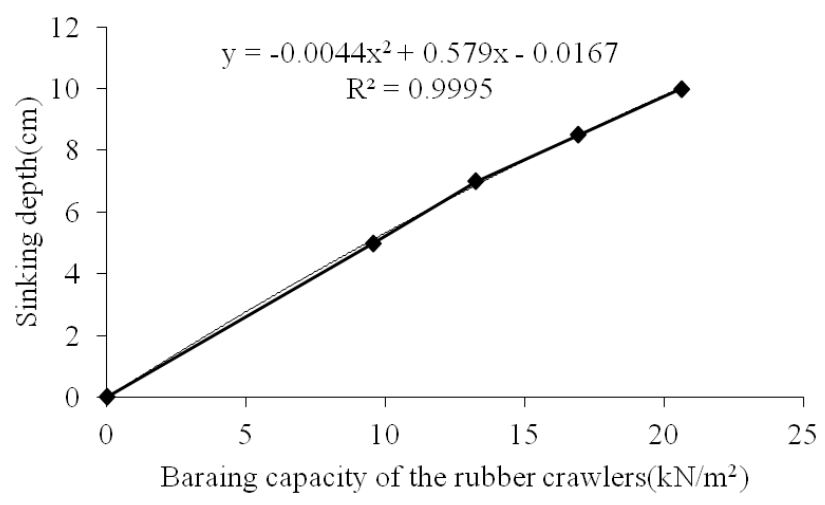

Figure 6. Sinking depth of the test rubber crawler vehicle. 

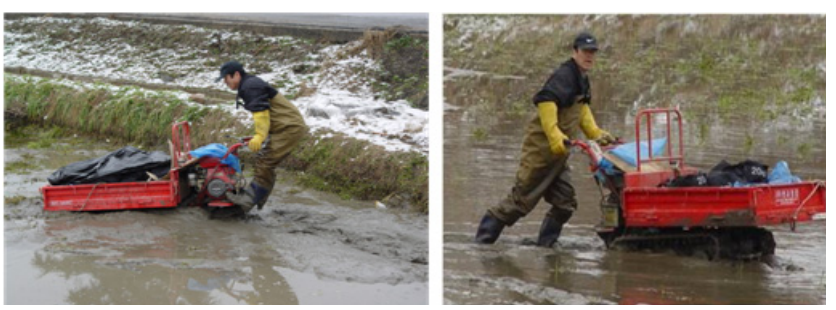

Figure 7. View of the driving test for the test crawler vehicle.

was due to the sinking of the crawler resulting in the test rubber crawler slipping continuously out of place. This condition was caused by the rolling resistance of the rear-end part rubber crawler with the semi-circular shape and radius of $120 \mathrm{~mm}$.

As shown at Figure 6, the sinking depth of the test vehicle was $100 \mathrm{~mm}$ deep under the bearing capacity of $20.61 \mathrm{kN} / \mathrm{m}^{2}$ of the crawlers (vehicle weight of $5.49 \mathrm{kN}$ ) and it was equivalent to $83 \%$ of the radius of $120 \mathrm{~mm}$ of the rear-end rubber crawler. This is similar like tire slip which occurs in soil surface when the rolling resistance of the tire is larger.

Specifically in the paddy field, the sinking of the rubber crawler occurs when the rolling resistance of the test rubber crawler is very high. Therefore, the shape of the rear-end rubber crawler has to be considered in the design of the inclined-like shape of the front-end rubber crawler for a reliable driving on the water contained paddy field. Drawbar pull of the test crawler vehicle was $1.47 \mathrm{kN}$ at the bearing capacity of $20.61 \mathrm{kN} / \mathrm{m}^{2}$. Figure 7 shows a view of the driving test for the test crawler vehicle.

\section{Field testing for the prototype crawler vehicle} Side-overturn angle of the prototype vehicle

The side-overturn angle of the prototype was tested using the side-overturn angle measuring device. Result of the side-overturn angle of the prototype vehicle was $26.4^{\circ}$.

\section{Sinking depth, slip rate and drawbar pull of the prototype vehicle}

Driving conditions of the prototype vehicle in water contained paddy field were good at both forward and backward driving test conditions at the prototype vehicle weights (5.59 kN, $7.64 \mathrm{kN}, 9.21 \mathrm{kN})$ are applied on the prototype. The sinking depth of the prototype rubber crawler was $0.13 \mathrm{~m}$ at the bearing capacity of 28.42 $\mathrm{kN} / \mathrm{m}^{2}$ and it agreed well with results calculated from the

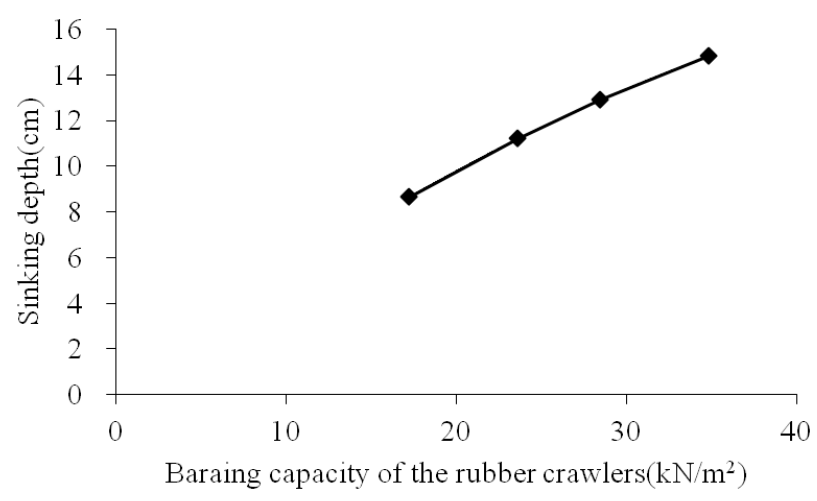

Figure 8. Sinking depth of the crawler of prototype vehicle.

Table 5. The slip ratio of crawler of the prototype vehicle in water-contained paddy field

\begin{tabular}{|c|c|c|c|}
\hline \multirow{2}{*}{$\begin{array}{l}\text { Level of } \\
\text { shift } \\
\text { gear }^{1}\end{array}$} & \multicolumn{2}{|c|}{ Driving speed $(\mathrm{m} / \mathrm{s})$} & \multirow{2}{*}{$\begin{array}{c}\text { Slip ratio of crawler } \\
(\%) \\
{[(a-b) / b]^{*} 100}\end{array}$} \\
\hline & $\begin{array}{l}\text { Water paddy } \\
\text { field (a) }\end{array}$ & $\begin{array}{c}\text { Concrete } \\
\text { pavement (b) }\end{array}$ & \\
\hline I & 0.070 & 0.072 & 2.7 \\
\hline II & 0.142 & 0.143 & 0.4 \\
\hline III & 0.204 & 0.217 & 6.0 \\
\hline
\end{tabular}

Foot Note: I (low speed), II (middle speed), III(high speed)

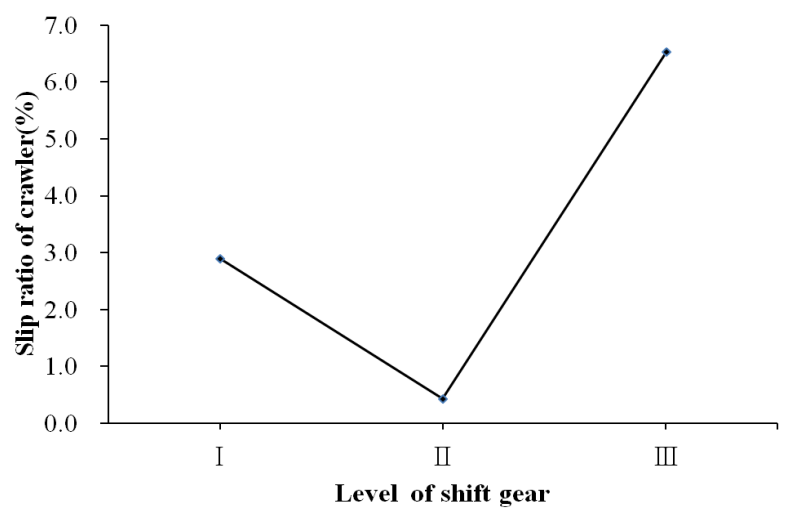

Figure 9. The relationship of slip ratio between crawlers of the prototype and water-contained paddy field.

functional formula of figure 6 . At the sinking depth at the bearing capacity of $34.78 \mathrm{kN} / \mathrm{m}^{2}$, driving performance of the prototype rubber crawler was good. Figure 8 is sinking depth of the crawler of prototype vehicle.

Also, the slip ratio of the prototype under driving speeds in the water contained paddy field is shown in Table 5. Figure 9 is the relationship of slip ratio between crawlers of the prototype and water-contained paddy field.

The slip ratio of the crawler of the prototype at the shift gear level III was $6.0 \%$ higher than the slip ratio of $0.4 \%$ 


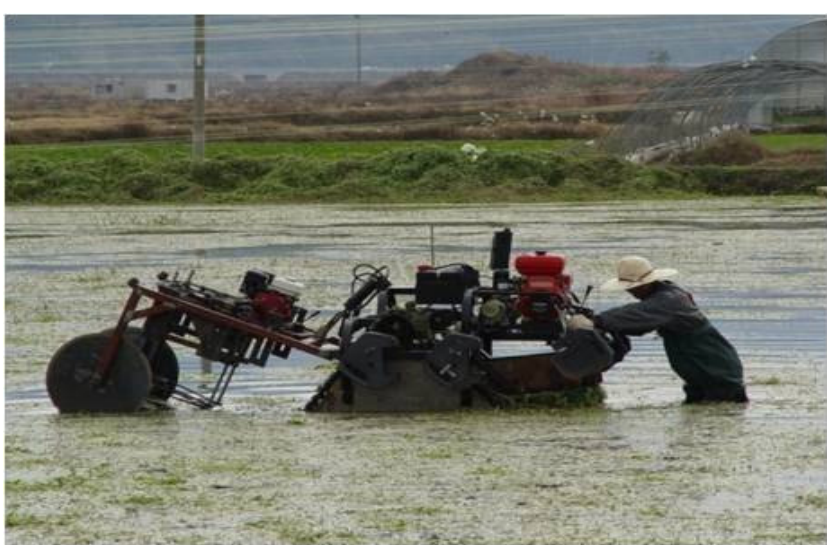

Figure 10. View of driving test of the prototype crawler vehicle.

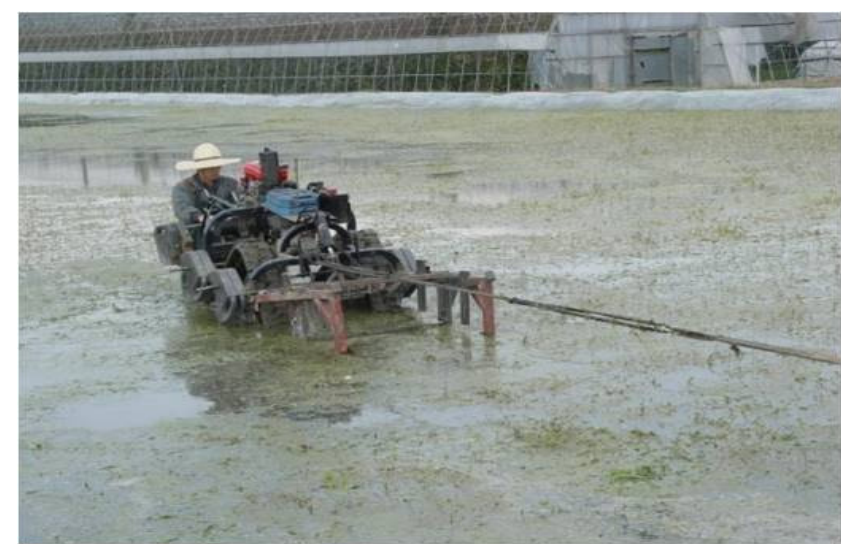

Figure 11. View of drawbar pull test of the prototype crawler vehicle.

of crawler at shift gear level $\Pi$. Accordingly, the slip ratio of the prototype in water contained paddy field was higher when the driving speed of the prototype was faster. Figure 10 shows a view of driving test of the prototype crawler vehicle.

The drawbar pull of the prototype vehicle was $3.5 \mathrm{kN}$ in the paddy field at a weight of $8.51 \mathrm{kN}$ and rubber crawler bearing capacity of $26.3 \mathrm{kN} / \mathrm{m}^{2}$. Figure 11 shows a view of drawbar pull test of the prototype crawler vehicle.

\section{Conclusions}

The side-overturn angle of the prototype was tested using the side-overturn angle measuring device. Result of the side-overturn angle of the prototype vehicle was $26.4^{\circ}$.

Driving performance of the prototype vehicle in water contained paddy field were good at both forward and reverse (backward) directions as weights were applied.
The sinking depth of the prototype rubber crawler was $0.13 \mathrm{~m}$ and it was proportional to the weight of the prototype vehicle.

However, at sinking depth of $0.13 \mathrm{~m}$ of the prototype rubber crawler, there was not much effect on driving of the prototype.

The ratio of crawler slip of the prototype at the shift gear level III was $6.0 \%$ higher than the ratio of $0.4 \%$ of crawler slip at shift gear level $I$. Accordingly, the ratio of the slip of the prototype in water contained paddy field was higher when the driving speed of the prototype was faster.

The drawbar pull of the prototype vehicle was $3.5 \mathrm{kN}$ in the water-contained paddy field at the rubber crawler bearing capacity of $26.3 \mathrm{kN} / \mathrm{m}^{2}$ ( prototype vehicle weight of $8.51 \mathrm{kN}$ ).

\section{Conflict of Interest}

No potential conflict of interest relevant to this article was reported.

\section{Acknowledgement}

This study was carried out with the support of "Research Program for Agricultural Science \&Technology Development (Project No PJ 006890)", National Academy of Agricultural Science, Rural Development Administration, Republic of Korea.

\section{References}

Inaba, S., E. Inoue, K. Hashiguchi and T. Matsuo. 2000. Analytical simulation of travel resistance of the rubber crawler system for farm machinery. Agricultural mechanization in Korea (Korean Society for Agricultural Machinery), 2(14):139-145.

Jun, H. J., Y. Choi., C. K. Lee., D. K. Choi., T. K. Kang and C. S. Lee. 2009. Fundamental Studies on Mechanization of Harvesting for Dropwort by Root cutting. Korean Society for Agricultural Machinery, Proceedings of the KSAM 2009 winter conference. 2009 Feb 19, Busan Univ., Milyang, 14(1):211-214.

Jun, H. J., T. K. Kang., C. S. Lee., C. K. Lee., D. K. Choi and C. 
Choi. 2011. Study on a crawler type vehicle for operating in deep water paddy rice field planted with water. Proceedings of the XXXIV COISTA CIGR V Conference 29 June - 01 July 2011, Univ. of National Resources and Applied Life Sciences, Vienna-Austria, 276-278.

Matsuo, T., S. Inaba, J. Sakai and E. Inoue. 1993. Studies on design theories of the rubber crawler for a farm machinery. Korean Society for Agricultural Machinery, Proceedings of International Conference for agricultural machinery \& Process engineering. Oct. 19-22, 1993, Seoul Korea 1202-1211.

Michael, W. 1996. Soil compaction and tractive force of big tractors and caterpillars (challenger 65\&45). ICAMPE of Korean society for agricultural machinery 2:404-412. Nikolic. 1993. Tractive performance comparison between wheel-drive tractors and a rubber belt crawler tractor. Korean Society for Agricultural Machinery, Proceedings of International Conference for agricultural machinery \& Process engineering. Oct. 19-22, 1993, Seoul Korea, 1196-1201.

Park, W. Y., Y. C. Chang and K. S. Lee. 2003. Prediction of tractive performance of tracked vehicles using a computer simulation model. Journal of biosystems engineering of the Korean society for agricultural machinery, 4(1):34-38. 